\title{
Alloying Elements Effects on Electrical Conductivity and Mechanical Properties of Newly Fabricated Al Based Alloys Produced by Conventional Casting Process
}

\author{
Hany S. Abdo (D), Asiful H. Seikh*(D), Jabair Ali Mohammed (D) and Mahmoud S. Soliman (D) \\ Mechanical Engineering Department, King Saud University, P.O. Box 800, Al-Riyadh 11421, Saudi Arabia; \\ habdo@ksu.edu.sa (H.S.A.); jmohammed@ksu.edu.sa (J.A.M.); solimanm@ksu.edu.sa (M.S.S.) \\ * Correspondence: aseikh@ksu.edu.sa
}

check for updates

Citation: Abdo, H.S.; Seikh, A.H.; Mohammed, J.A.; Soliman, M.S. Alloying Elements Effects on Electrical Conductivity and Mechanical Properties of Newly Fabricated Al Based Alloys Produced by Conventional Casting Process. Materials 2021, 14, 3971. https:// doi.org/10.3390/ma14143971

Academic Editor:

Tomasz Trzepiecinski

Received: 1 July 2021

Accepted: 14 July 2021

Published: 16 July 2021

Publisher's Note: MDPI stays neutral with regard to jurisdictional claims in published maps and institutional affiliations.

Copyright: (c) 2021 by the authors. Licensee MDPI, Basel, Switzerland. This article is an open access article distributed under the terms and conditions of the Creative Commons Attribution (CC BY) license (https:// creativecommons.org/licenses/by/ $4.0 /)$.

\begin{abstract}
The present investigation deals with a comprehensive study on the production of aluminum based alloys with the incorporation of different alloying elements and their effect on its electrical conductivity and mechanical properties. Casting of pure aluminum with different concentration and combinations of alloying additives such as cupper $(\mathrm{Cu})$, magnesium $(\mathrm{Mg})$ and silver $(\mathrm{Ag})$ were carried out using a graphite crucible. The as-cast microstructure was modified by hot rolling followed by different heat-treated conditions viz., annealing, normalizing, quenching, and age hardening. The mechanical properties and electrical conductivity of the produced heat-treated alloys sheets under various processing conditions were carried out using tensile testing, hardness, and electrical resistivity measurements. It was found that by increasing the alloying elements content, yield strength results increased significantly by more than $250 \%$ and $500 \%$ for the as rolled and $8 \mathrm{~h}$ aged $\mathrm{Al}-\mathrm{Cu}-\mathrm{Mg}$ alloy, respectively. On the other hand, the electrical conductivity reduces slightly with $-14.6 \%$ and $-16.57 \%$ for the as rolled and $8 \mathrm{~h}$ aged of the same $\mathrm{Al}-\mathrm{Cu}-\mathrm{Mg}$ alloy, respectively.
\end{abstract}

Keywords: aluminum alloys; casting; heat treatment; conductivity; mechanical strength

\section{Introduction}

Aluminum and its alloys have very wide applications in a variety of fields such as aircrafts, aerospace, vehicles, electricity, building, packaging, electronic, and kitchen utensils etc.), mostly due to its light weight, corrosion resistance, and good electrical and mechanical properties. The high strength to mass (strength/weight) ratio of aluminum alloys is superior to that of almost all other engineering materials. Aluminum is classified as a light metal and its strength can be improved by alloying, mechanical, and heat treatment, thereby improving its mechanical properties $[1,2]$. Presently, researchers and scientists worldwide have focused their attention on improving both the mechanical and electrical properties of aluminum for its use in a wide range of applications.

From the last two decades, due to the increase in demand from the electricity transmission lines, copper is being replaced by $\mathrm{Al}$ because of its light weight and relatively low cost [3]. In addition, among the engineering conductor materials, aluminum has a very good electrical conductivity due to lower specific gravity (almost in the second rank after copper). The replacing of copper by aluminum for electricity transmission by overhead ACSR (aluminum conductor steel-reinforced) conductors, power cables, etc. has increased all over the world. Moreover, substitution of copper by aluminum also takes place in countries which have enough resources from copper, since it shows a good economical advantage as serious competitor against copper.

The electrical conductivity of aluminum is high enough due to the huge number of free electrons rotating around its lattice structure [4]. However, the electrical conductivity of the commercially pure aluminum is higher than all aluminum materials and alloys. It has limited application because of its very low mechanical strength and toughness [5-7]. 
The demand for high strength and highly electrically conductive Al alloys for power transmission lines (e.g., wire and cable applications) has increased. Practically, by adding alloying elements to pure aluminum, aluminum's strength can be significantly improved. However, on the other hand a great reduction in the electrical conductivity takes place due to the solute atoms and impurities generated by substitution of alloying elements. Another process affecting the electrical conductivity of aluminum is the heat treatment process, since elements in the solid solution phase represent a higher resistance than non-dissolved elements. That is why it is a great challenge to play with the strength of the pure aluminum in such a way that the decrease in its electrical conductivity will be still acceptable and valid for the selected application.

Since the electrical conductivity and the mechanical strength are most imperative properties for producing conductor materials, development of an aluminum conductor with a suitable combination from acceptable strength and high conductivity represents the main condition for using aluminum in electrical transmission cables. The electric conductivity property is affected by the metallic material's microstructure, since it is very sensitive to the disturbance of electrons scattering due to any defects or solutes in the crystal structure. It has been seen for most age-hardened aluminum alloys that the relation between electrical conductivity versus hardness and tensile strength is " $\mathrm{C}$-shaped" as reported by Hagemaier [8]. Initially, hardness of age-hardenable aluminum alloys decreases as the electrical conductivity increases because of the limited solubility in the solid solution phase, which affects the precipitation rate and generates many different phases. The opposite trend is valid at high temperature values, as low conductivity is associated with higher hardness values (which could be due to the dissolving back of the precipitates into the main matrix elements) [8].

Accordingly, recent studies and research activities have been trying to focus on developing high strength aluminum alloys with high electrical conductivity properties through novel processing and fabrication routes [9]. The improved properties can be achieved by many methods such as cold working, heat treatment, and adding alloying elements to the aluminum matrix. Addition of alloying elements including minor elements, major elements, and microstructure impurities can control the required strength and electrical conductivity of the alloy.

Alloying elements such as copper, magnesium and silver offer superb mechanical properties of the alloy at higher temperature values. Moreover, creep resistance is improved due to the uniform and fine precipitate distribution formed along the boundaries [10-12]. Additional benefits of copper additives include increasing the hardness and strength of aluminum casting alloys at all temperature levels and all heat treatment conditions, which leads to an improvement of the machinability of the fabricated alloys [13]. As a negative effect for adding copper as alloying elements, however, the low corrosion resistance of the aluminum-copper alloys increases the stress corrosion susceptibility in certain alloys and temperatures. Other alloying elements such as magnesium $(\mathrm{Mg})$, have the potential to improve the hardness characteristics of aluminum alloys via substantial strengthening mechanisms. Thus, weldability, corrosion resistance and high mechanical strength can be achieved easily by using Mg additives.

Salihu et al. [14] studied the effect of adding $\mathrm{Mg}$ and ageing on the mechanical properties and microstructure of $\mathrm{Al}-\mathrm{Cu}-\mathrm{Mg}$ alloys. They reported that the increase in $\mathrm{Mg}$ percentage leads to an increase in hardness and tensile strength for the studied alloys; the addition of $2.5 \mathrm{wt} \% \mathrm{Mg}$ can improve hardness by $23 \%$, while tensile strength can be improved by $70 \%$. They also investigated whether the addition of $\mathrm{Mg}$ has a good effect on ageing process due to grain refinement which reflect on the mechanical properties of the Aluminum alloy.

The effect of using silver into Aluminum alloys have been reported, but still quite little research articles are available in this field. The mechanical properties and microstructures of $\mathrm{Al}-\mathrm{Mg}-\mathrm{Cu}-\mathrm{Ag}$ alloys are very sensitive to heat treatment parameters and deformation conditions [15-17]. The addition of silver to aluminum- $4 \mathrm{wt} \%$-copper alloy slows down 
the ageing rate of the low temperature limit, which provides a chance for hardening to take place by the expanding ageing time. More addition percentage of Ag to Al-Cu alloy will cause great precipitation hardenability [18] and high temperature stability [19,20]. Thus, adding Ag into Al-Mg-Cu alloy changes the phase formations conditions and slows down the degradation of the alloy at elevated temperatures levels [20]. The crystallographic orientation and chemical composition of Al-Cu-Mg alloys is affected by the addition of silver in the range of about $0.5 \%$ through artificial ageing, which improves the phase precipitation rate [20-24].

Earlier, Allen et al. worked on a few aluminum alloys and recommended a valuable relationship between tensile strength, hardness and electrical conductivity for 7079-T6, 7178T6, 7075-T6, and 7002-T6 only. No such relation was found for other types of aluminum alloys [25-27]. Hagemaier reported that it was possible to find out the actual residual yield strength of 2024-T3/T4 and 7075-T6 alloys using hardness and electrical conductivity measurements [8].

To compare these overviewed alloys with other aluminum series alloys, it is observed that it has a very low strength, which we try to improve through this study. The major properties considered when choosing these alloys for structural application is their greater mechanical properties and electrical conductivity. In order to achieve this target, the current investigation will be focused on studying the electrical and mechanical properties of newly developed aluminum alloys, based on experimental design, varying chemical composition, cold working, heat treatment, and the aging process.

\section{Experimental}

The experimental work was carried out on pure $\mathrm{Al}$ and four different $\mathrm{Al}$ alloys (Table 1) produced by direct chill casting in our lab to select the best option out of them. The commercially available aluminum, copper, silver and magnesium were weighed, added to the pure $\mathrm{Al}$ powder, and then heated in the graphite crucible at $730{ }^{\circ} \mathrm{C}$ for $3 \mathrm{~h}$ to get the desired $\mathrm{Al}$ alloy. The chemical compositions of $\mathrm{Al}$ alloys (wt\%) are given in Table 1. After heating, the molten metal is then poured into the pre-heated molds in order to get a solid as-cast sample $5 \times 10 \mathrm{~cm}^{2}$ rectangle. The as-cast samples were then homogenized in a vacuum furnace at $540{ }^{\circ} \mathrm{C}$ for $24 \mathrm{~h}$.

Table 1. Pure Al and four different aluminum alloys composition.

\begin{tabular}{ccccc}
\hline Alloy & Al & Cu & Mg & Ag \\
\hline 1 & 100 & - & - & - \\
\hline 2 & Bal & 2 wt. $\%$ & - & - \\
\hline 3 & Bal & 2 wt. $\%$ & - & 0.5 wt. $\%$ \\
\hline 4 & Bal & 2 wt. $\%$ & 0.5 wt. $\%$ & - \\
\hline 5 & Bal & 2 wt. $\%$ & 0.5 wt. $\%$ & 0.5 wt. $\%$ \\
\hline
\end{tabular}

After homogenization, the samples were hot rolled by heating the samples at $450{ }^{\circ} \mathrm{C}$ for $30 \mathrm{~min}$ maintaining the temperature of the rolls at $150^{\circ} \mathrm{C}$. The samples were hot rolled for multiple passes until $80-85 \%$ of the reduction ratio onto the sample was achieved. The samples were subjected to $7-8 \%$ of reduction in each pass and by interim heating of the sample in the furnace after each pass as shown in Figure 1.

\subsection{Heat Treatment}

Various heat treatments were used to study the behavior of the alloys and to assist the alloying elements which were segregated from aluminum during cooling down from melting phase while casting to get diffused and homogeneous solid diffusion of the alloying elements. The samples were heated at $540{ }^{\circ} \mathrm{C}$ for $30 \mathrm{~min}$ in vacuum furnace followed by quenching, air cooling and furnace cooling, or annealing as shown in Figure 2. The quenched samples were then aged at $200^{\circ} \mathrm{C}$ for $1 \mathrm{~h}, 4 \mathrm{~h}$, and $8 \mathrm{~h}$, respectively. 


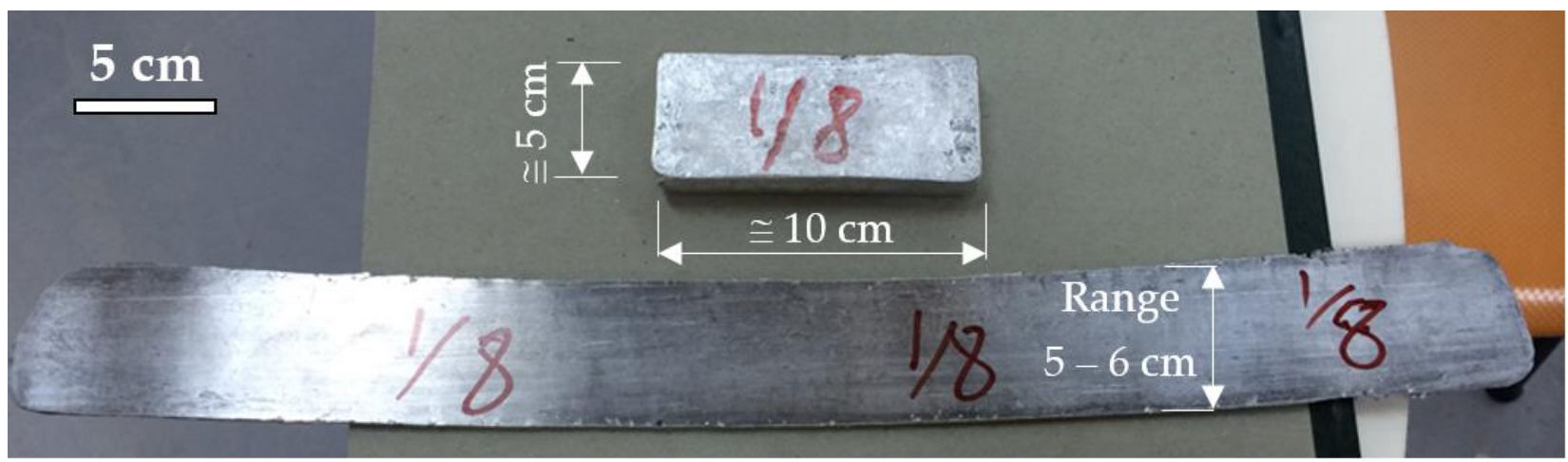

Figure 1. Alloys Before and after rolling.



Figure 2. Schematic diagram for the heat treatment process applied.

The second step after heat treatment is annealing, in which the recrystallization effect can happen and to remove internal stresses. The obtained properties of the alloy are controlled by the its chemical composition, thickness of its cross section, and the cooling rate applied.

\subsection{Mechanical Testing}

Tensile specimens of the alloys were prepared by wire cutting in accordance with ASTM standards. The testing machine of INSTRON 5900 series was used with load cell capacity of $150 \mathrm{KN}$. The cross-head speed was fixed at $1.08 \mathrm{~mm} / \mathrm{min}$ corresponding to $10-3$ strain rate. The stress and strain were calculated using the load and displacement obtained from the machine. The tests were performed at room temperature. For hardness and conductivity measurements, square pieces $(10 \mathrm{~mm} \times 10 \mathrm{~mm})$ of specimens with $2.5 \mathrm{~mm}$ thickness were cut.

\subsection{Conductivity Measurement}

From Ohm's law, $\mathrm{R}=\mathrm{V} / \mathrm{I}$, where $\mathrm{V}$ is the Voltage applied on the specimen, $\mathrm{I}$ is the passing current in Amp, resistance of the specimen towards electricity flow (R) can be calculated in Ohms $(\Omega)$. Inverse of resistivity is the electrical conductivity $(\sigma)$ which is given as $\sigma=1 / \rho$. While resistivity ( $\rho$ in $\Omega \mathrm{m}$ ) can be obtained by using the equation: 
$\rho=\mathrm{RA} / \mathrm{L}$, where $\mathrm{R}$ is the resistance of the sample against to the electricity flow, A is the sample cross-sectional area in $\mathrm{m}^{2}$, and $\mathrm{L}$ is the sample length in meter.

The as rolled and heat-treated square pieces' specimens were mirror polished prior to conductivity measurement. Conductivity was measured in a 4-point probe instrument (Model 6221, Keithley Instruments, Inc., Solon, OH, USA) which is a combined digital voltmeter and constant current source. The combination of four-points probe equipment is able to deliver a constant current source in order to measure volume resistivity or sheet resistance and resultant voltage. Resistivity of the alloys were measured and conductivity values were calculated.

\section{Results and Discussions}

Micro-hardness values of the as-rolled as well as the heat-treated aluminum alloys were given in Table 2 below. It can be seen that hardness values of as rolled product is higher than all heat-treated conditions for all alloys. The hardness of the as-cast sample is significantly affected by the heat treatment processes (Figure 3), with the tempered (aged) after $1 \mathrm{~h}$ sample having lowest hardness. The hardness also increased further after $8 \mathrm{~h}$ of aging treatment. With the exception of the quenched sample in which significant increase in hardness is attained, other heat treatment processes have little effect on the hardness characteristic of the alloys (Table 2).

Table 2. Hardness (HV) values of different heat-treated alloys.

\begin{tabular}{ccccccccc}
\hline Samples & $\begin{array}{c}\text { As } \\
\text { Rolled }\end{array}$ & $\begin{array}{c}\text { Air Cooled } \\
\text { Normalized }\end{array}$ & $\begin{array}{c}\text { Furnace } \\
\text { Cooled/Annea }\end{array}$ & Quenched & \multicolumn{2}{c}{ Aging- } & Aging- & Aging-8 \\
1/Tempered & A & Aging \\
\hline $\mathrm{Al}$ & 25.47 & 24.53 & 23.60 & 25.37 & 23.93 & 23.43 & 25.10 \\
\hline $\mathrm{Al}-2 \% \mathrm{Cu}$ & 55.56 & 42.08 & 45.56 & 54.62 & 42.92 & 45.88 & 51.74 \\
\hline $\mathrm{Al}-2 \% \mathrm{Cu}-0.5 \% \mathrm{Ag}$ & 75.23 & 68.23 & 60.10 & 68.30 & 55.57 & 62.83 & 72.10 \\
\hline $\mathrm{Al}-2 \% \mathrm{Cu}-0.5 \% \mathrm{Mg}$ & 98.37 & 83.60 & 77.83 & 91.67 & 76.57 & 83.77 & 91.10 \\
\hline $\mathrm{Al}-2 \% \mathrm{Cu}-0.5 \% \mathrm{Ag}-0.5 \% \mathrm{Mg}$ & 93.60 & 81.33 & 77.47 & 81.43 & 71.27 & 78.43 & 85.87 \\
\hline
\end{tabular}

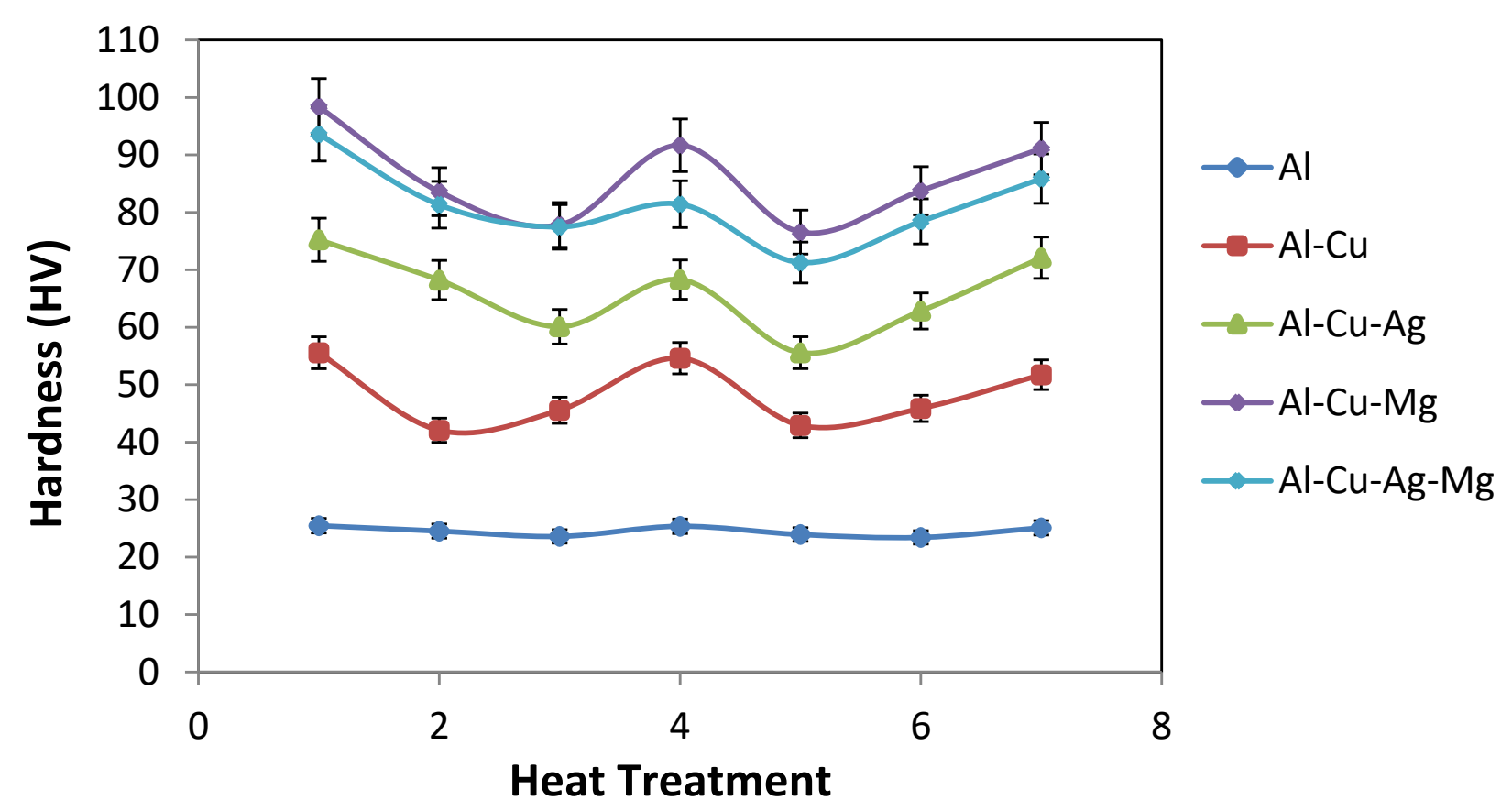

Figure 3. Variation of micro-hardness (HV) with heat treatment of different alloys. 
Stress-strain diagrams were plotted as shown in Figures 4 and 5 for as rolled and aging after $8 \mathrm{~h}$ condition and strength of the alloys were measured and presented in Table 3 . The variations of strength of as rolled and different heat-treated conditions are shown in Figure 6.

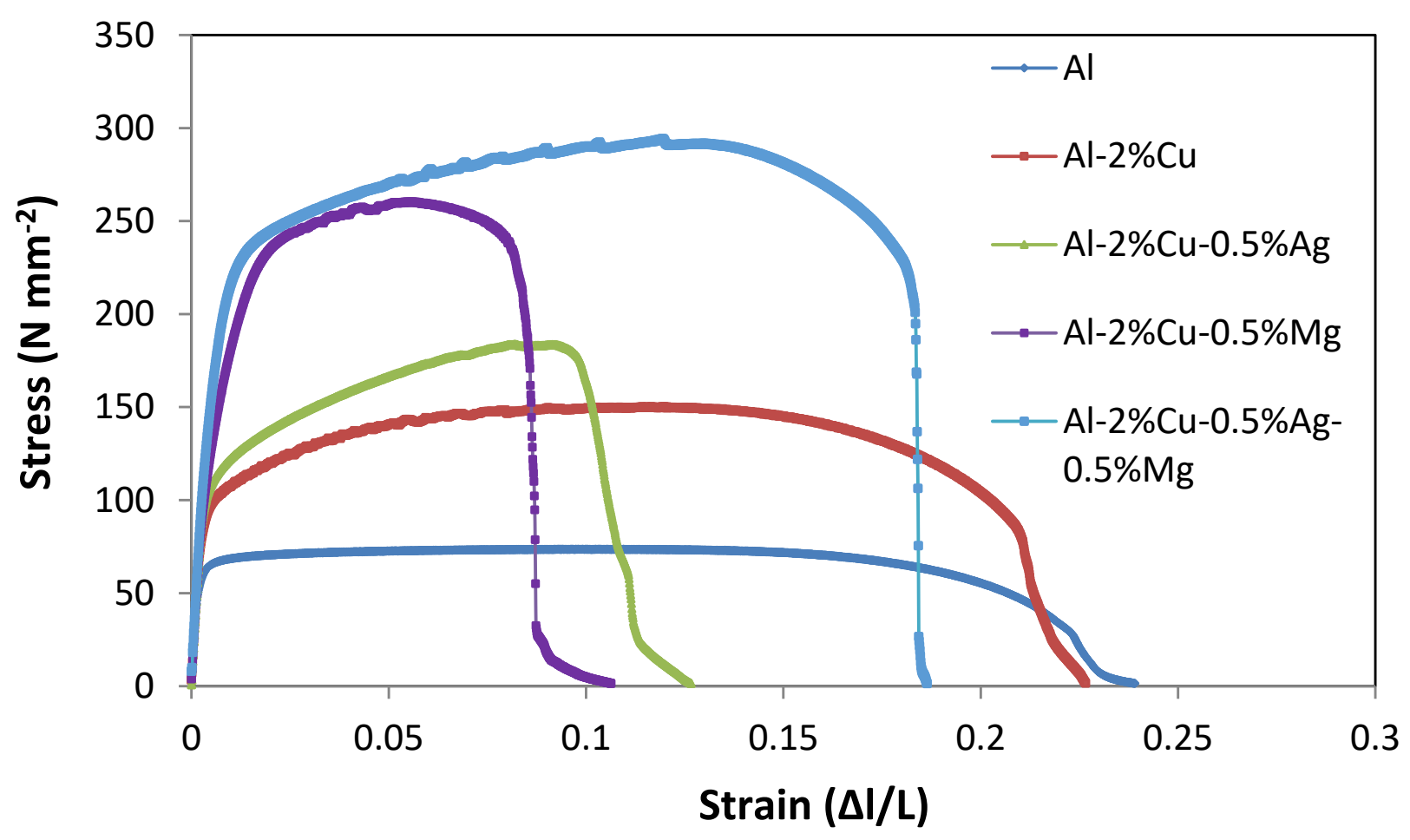

Figure 4. Stress-strain diagram of different alloys in as rolled conditions.

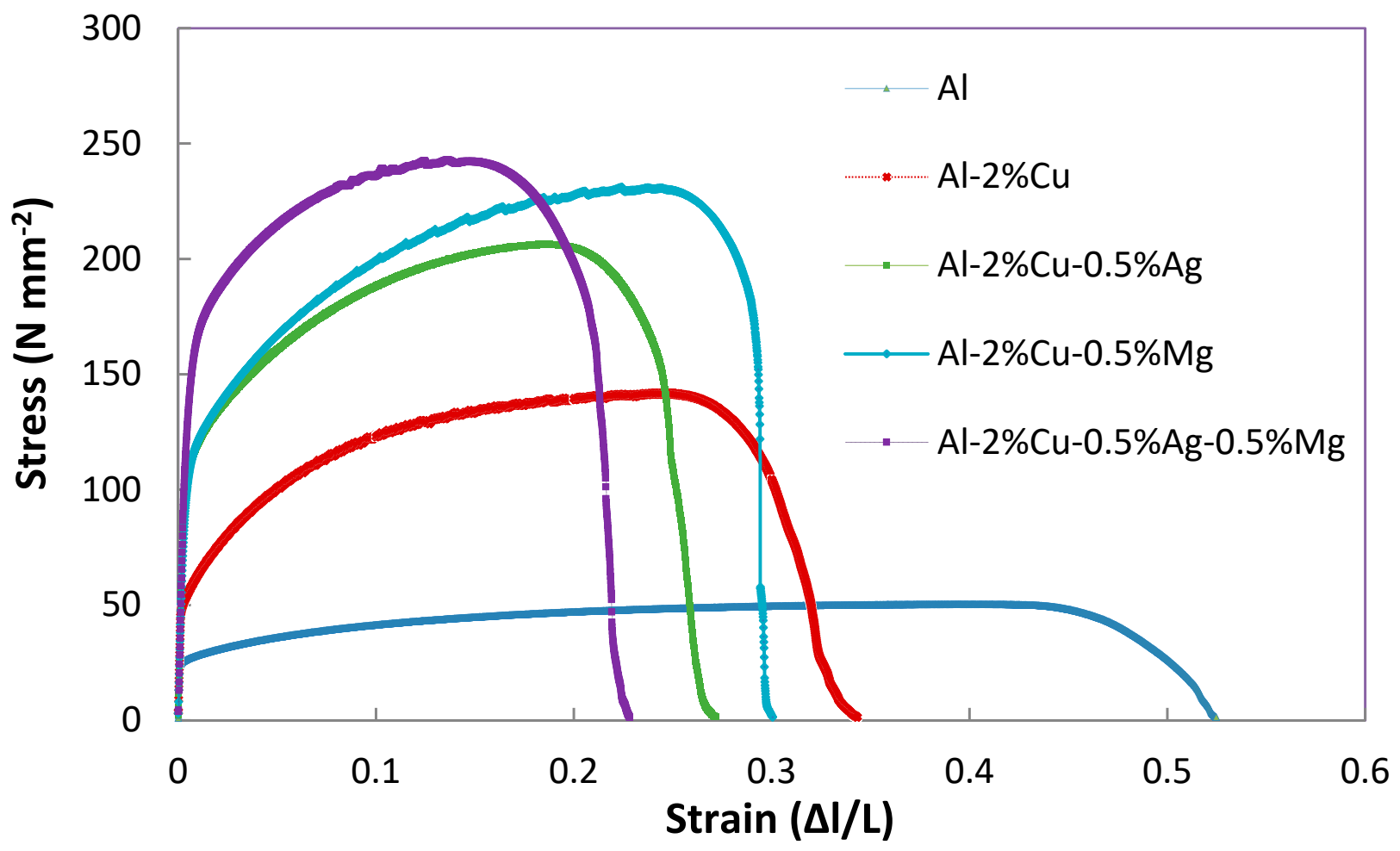

Figure 5. Stress-strain diagram of different alloys in age hardening conditions. 
Table 3. Yield Strength $\left(\mathrm{N} / \mathrm{mm}^{2}\right)$ values of different heat-treated alloys.

\begin{tabular}{ccccccccc}
\hline Samples & $\begin{array}{c}\text { As } \\
\text { Rolled }\end{array}$ & $\begin{array}{c}\text { Air Cooled } \\
\text { Normalized }\end{array}$ & $\begin{array}{c}\text { Furnace } \\
\text { Cooled/Annea }\end{array}$ & Quenched & \multicolumn{2}{c}{ Aging- } & $\begin{array}{c}\text { Aging- } \\
\text { 1/Tempered }\end{array}$ & Aging-8 \\
\hline $\mathrm{Al}$ & 65.79 & 24.53 & 23.6 & 25.37 & 23.93 & 23.43 & 25.8 \\
\hline $\mathrm{Al}-2 \% \mathrm{Cu}$ & 95.48 & 42.08 & 45.56 & 54.62 & 42.92 & 45.88 & 58.54 \\
\hline $\mathrm{Al}-2 \% \mathrm{Cu}-0.5 \% \mathrm{Ag}$ & 113.53 & 68.23 & 60.1 & 68.3 & 55.57 & 62.83 & 105.14 \\
\hline $\mathrm{Al}-2 \% \mathrm{Cu}-0.5 \% \mathrm{Mg}$ & 232.64 & 83.6 & 77.83 & 91.67 & 76.57 & 83.77 & 158.78 \\
\hline $\mathrm{Al}-2 \% \mathrm{Cu}-0.5 \% \mathrm{Ag}-0.5 \% \mathrm{Mg}$ & 216.28 & 80.33 & 74.47 & 81.43 & 71.27 & 78.43 & 115.17 \\
\hline
\end{tabular}

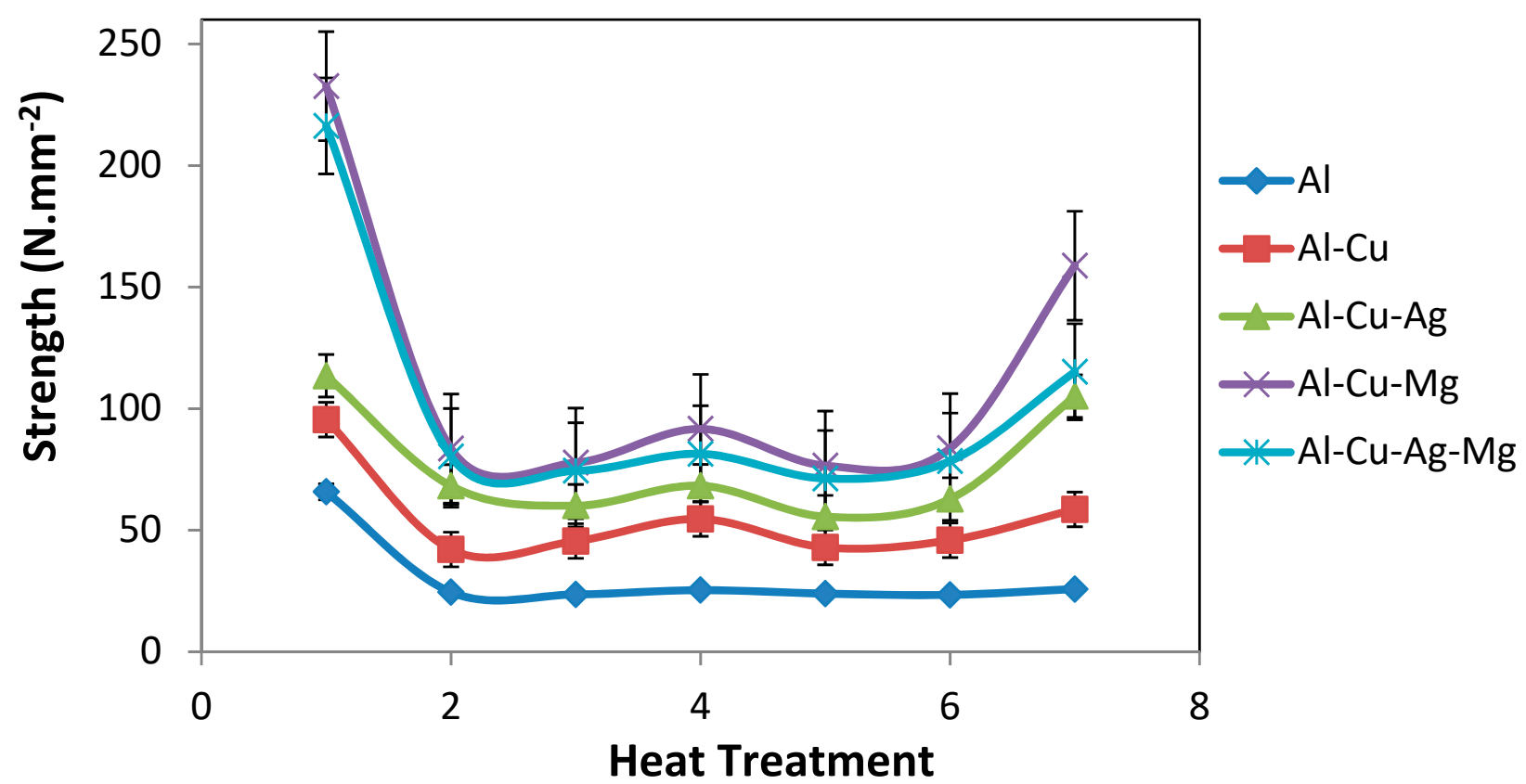

Figure 6. Variation of Strength $\left(\mathrm{N} / \mathrm{mm}^{2}\right)$ with heat treatment of different alloys.

It has been seen that the as-cast (as-rolled) specimens have the greatest yield strengths and ultimate tensile strength, then the age hardened specimens, quenched specimens, normalized and, in the last place, the annealed specimens. The presence of dislocations within the crystal structure due to the hot rolling process in the as-cast (as-rolled) structure allow it to get the highest strength and hardness among all of the samples, due to the brittleness effect gained by generating dislocations into the aluminum alloy. The variation in grain size after the heat treatment process for the remaining samples represents the main reason for low strength and hardness trend observed. That is exactly what Kenji et al. [28] concluded from their research work, which confirm that the grain refinement and the solid solution can contribute significantly to the aluminum-magnesium alloy hardening. Furthermore, it has been well reported in may previous researches that the large grained materials have less grain boundaries, and vice versa; fine grained materials have much more grain boundaries, and are thus stronger and harder than the large grained materials [29-32]. Another reason behind the higher hardness and toughness values for the age hardened samples over than quenched, normalized, and annealed samples is the dislocation motion during deformation, since it has more grain boundaries [33,34].

The electrical resistivity of all aluminum alloys in different heat-treated conditions was directly measured and the electrical conductivity was calculated and tabulated in Table 4. The conductivity values were compared for all heat treated as well as rolled samples as shown in Figure 7. 
Table 4. Conductivity (\%IACS) values of different heat-treated alloys.

\begin{tabular}{|c|c|c|c|c|c|c|c|}
\hline Samples & $\begin{array}{c}\text { As } \\
\text { Rolled }\end{array}$ & $\begin{array}{c}\text { Air Cooled } \\
\text { Normalized }\end{array}$ & $\begin{array}{c}\text { Furnace } \\
\text { Cooled/Annea }\end{array}$ & Quenched & $\begin{array}{c}\text { Aging- } \\
\text { 1/Tempered }\end{array}$ & $\begin{array}{c}\text { Aging- } \\
4\end{array}$ & Aging-8 \\
\hline $\mathrm{Al}$ & 60.53 & 62.82 & 63.4 & 60.87 & 61.46 & 62.03 & 62.42 \\
\hline $\mathrm{Al}-2 \% \mathrm{Cu}$ & 57.16 & 60.28 & 59.06 & 57.44 & 58.22 & 59.05 & 59.76 \\
\hline $\mathrm{Al}-2 \% \mathrm{Cu}-0.5 \% \mathrm{Ag}$ & 55.42 & 57.85 & 56.75 & 55.1 & 55.91 & 56.15 & 56.82 \\
\hline $\mathrm{Al}-2 \% \mathrm{Cu}-0.5 \% \mathrm{Mg}$ & 51.68 & 50.52 & 52.44 & 49.62 & 50.88 & 51.68 & 52.08 \\
\hline $\mathrm{Al}-2 \% \mathrm{Cu}-0.5 \% \mathrm{Ag}-0.5 \% \mathrm{Mg}$ & 53.54 & 52.64 & 53.74 & 51.26 & 52.72 & 53.62 & 54.18 \\
\hline
\end{tabular}

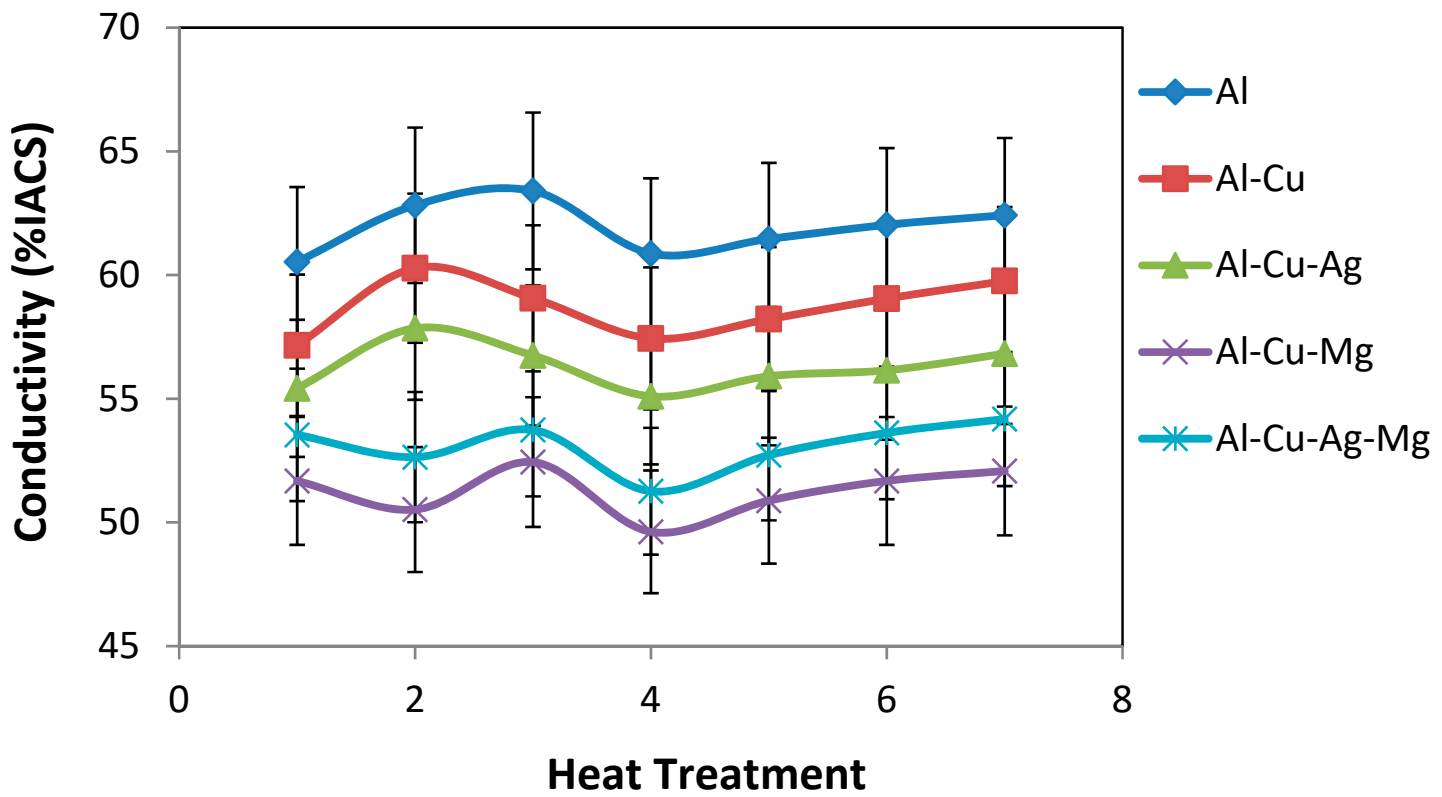

Figure 7. Variation of Conductivity (\%IACS) with heat treatment of different alloys.

\section{Conclusions}

Four different grades of aluminum alloys were produced by varying composition of alloying elements viz. $\mathrm{Cu}, \mathrm{Ag} \& \mathrm{Mg}$. The as-cast alloys were then hot rolled followed by heat treatment in different conditions such as annealing, normalizing, quenching, and age hardening at different time zones. Strength and hardness of the as-cast (as-rolled) specimens are found to be higher followed by age hardened specimens with an exception of the quenched sample which exhibited substantial increase in hardness value. This condition in as-cast (as-rolled) specimens is caused by the existence of dislocations defects within the crystal structure of the aluminum alloys, which causes brittleness in the samples. On the other hand, the presence of larger grain boundaries or the grain growth after heat treatment are the reason for low strength and hardness in the heat-treated samples. In order to summaries the effect of alloying elements addition on the mechanical properties and electrical conductivity by specific values, it was found that by increasing the alloying elements content, yield strength results increased significantly by more than $250 \%$ and $500 \%$ for the as-rolled and $8 \mathrm{~h}$-aged $\mathrm{Al}-\mathrm{Cu}-\mathrm{Mg}$ alloys, respectively. While the electrical conductivity reduces slightly with $-14.6 \%$ and $-16.57 \%$ for the as-rolled and $8 \mathrm{~h}$-aged of the same $\mathrm{Al}-\mathrm{Cu}-\mathrm{Mg}$ alloy, respectively.

For the same alloy, the electrical conductivity of the age hardened sample was found to be greater than that of the other treatments. The increased electrical conductivity in the age hardened samples may be attributed to temperature changes and grain disassociation. As a result, the age hardened samples exhibited greater strength and conductivity. More research in this area is required to attain high electrical conductivity properties using innovative processing techniques and regulating the microstructural impurities in the alloy. 
Author Contributions: Conceptualization, H.S.A., A.H.S. and M.S.S.; methodology, H.S.A. and J.A.M.; software, H.S.A. and J.A.M.; validation, H.S.A. and M.S.S.; formal analysis, A.H.S. and J.A.M.; investigation, H.S.A.; resources, H.S.A.; data curation, A.H.S., J.A.M. and M.S.S.; writing-original draft preparation, H.S.A.; writing-review and editing, H.S.A.; visualization, A.H.S.; supervision, H.S.A.; project administration, A.H.S.; funding acquisition, A.H.S. All authors have read and agreed to the published version of the manuscript.

Funding: The authors would like to acknowledge the Researchers Supporting Project number (RSP-2021/373), King Saud University, Riyadh, Saudi Arabia.

Institutional Review Board Statement: Not applicable.

Informed Consent Statement: Not applicable.

Data Availability Statement: The data presented in this study are available on reasonable request from the corresponding author.

Acknowledgments: This research is funded by Researchers Supporting Project number (RSP2021/373), King Saud University, Riyadh, Saudi Arabia.

Conflicts of Interest: The authors declare no conflict of interest.

\section{References}

1. Totten, G.E.; MacKenzie, D.S. Handbook of Aluminum. Vol. 2, Alloy Production and Materials Manufacturing; Marcel Dekker: New York, NY, USA, 2003.

2. Polmear, I.J. Light Alloys—Metallurgy of the Light Metals; Arnold: London, UK, 1995.

3. Abdo, H.S.; Khalil, K.A.; El-Rayes, M.M.; Marzouk, W.W.; Hashem, A.M.; Abdel-Jaber, G.T. Ceramic nanofibers versus carbon nanofibers as a reinforcement for magnesium metal matrix to improve the mechanical properties. J. King Saud Univ. Eng. Sci. 2020, 32, 346-350. [CrossRef]

4. Holman, J.P. Heat Transfer, 7th ed.; McGraw-Hill Book Company: Singapore, 1990; pp. 1-20.

5. Meshchanov, G.I.; Peshkov, I.B. Innovative approaches in domestic cable engineering. Russ. Electr. Eng. 2010, 81, 1-8. [CrossRef]

6. Vorontsova, L.A.; Maslov, V.V.; Peshkov, I.B. Aluminum and Aluminum Alloys in Electrical Products; Energiya: Moscow, Russia, 1971. (In Russian)

7. Lanker, V. Metallurgy of Aluminum Alloys; William Clones and Sons Ltd., Chapman and Hall: London, UK, 1967; pp. 236-248.

8. Hagemaier, D.J. Evaluation of heat damage to aluminium aircraft structures. Mater. Eval. 1982, 40, 942-969.

9. Valiev, R.Z.; Murashkin, M.Y.; Ganeev, A.V.; Enikeev, N.A. Superstrength of nanostructured metals and alloys produced by severe plastic deformation. Phys. Met. Metallogr. 2012, 113, 1193-1201. [CrossRef]

10. Bakavos, D.; Prangnell, P.B.; Bes, B.; Eberl, F. The effect of silver on microstructural evolution in two 2xxx series Al-alloys with a high Cu:Mg ratio during ageing to a T8 temper. Mater. Sci. Eng. A 2008, 491, 214-223. [CrossRef]

11. Fouly, A.; Almotairy, S.M.; Aijaz, M.O.; Alharbi, H.F.; Abdo, H.S. Balanced Mechanical and Tribological Performance of HighFrequency-Sintered Al-SiC Achieved via Innovative Milling Route-Experimental and Theoretical Study. Crystals 2021, 11, 700. [CrossRef]

12. Eddahbi, M.; Jiménez, J.A.; Ruano, O.A. Microstructure and creep behaviour of an Osprey processed and extruded Al-Cu-MgTi-Ag alloy. J. Alloys Compd. 2007, 433, 97-107. [CrossRef]

13. Xiao, D.H.; Wang, J.N.; Ding, D.Y.; Chen, S.P. Effect of $\mathrm{Cu}$ content on the mechanical properties of an $\mathrm{Al}-\mathrm{Cu}-\mathrm{Mg}-\mathrm{Ag}$ alloy. J. Alloys Compd. 2002, 343, 77-81. [CrossRef]

14. Salihu, S.A.; Isah, A.; Evarastics, P. Influence of Magnesium Addition on Mechanical Properties and Microstructure of Al-Cu-Mg Alloy. IOSR J. Pharm. Biol. Sci. 2012, 4, 15-20. [CrossRef]

15. Chang, C.-H.; Lee, S.-L.; Lin, J.-C.; Yeh, M.-S.; Jeng, R.-R. Effect of Ag content and heat treatment on the stress corrosion cracking of Al-4.6Cu-0.3Mg alloy. Mater. Chem. Phys. 2005, 91, 454-462. [CrossRef]

16. Ünlü, N.; Gable, B.M.; Shiflet, G.J.; Starke, E.A. The effect of cold work on the precipitation of $\Omega$ and $\theta^{\prime}$ in a ternary Al-Cu-Mg alloy. Metall. Mater. Trans. A 2003, 34, 2757-2769. [CrossRef]

17. Almotairy, S.M.; Alharthi, N.H.; Alharbi, H.F.; Abdo, H.S. Superior Mechanical Performance of Inductively Sintered Al/SiC Nanocomposites Processed by Novel Milling Route. Sci. Rep. 2020, 10, 10368. [CrossRef] [PubMed]

18. Jiang, D.-M.; Zhang, Y.-P. Effect of trace elements on structures and properties of aluminum alloys. Light Alloy Fabr. Technol. 2001, 29, 1-5. (In Chinese)

19. Murayama, M.; Hono, K. Role of Ag and Mg on precipitation of T1 phase in an Al-Cu-Li-Mg-Ag alloy. Scr. Mater. 2001, 44, 701-706. [CrossRef]

20. Ringer, S.P.; Yeung, W.; Muddle, B.C.; Polmear, I.J. Precipitate stability in Al-Cu-Mg-Ag alloys aged at high temperatures. Acta Metall. Mater. 1994, 42, 1715-1725. [CrossRef]

21. Raviprasad, K.; Hutchinson, C.R.; Sakurai, T.; Ringer, S.P. Precipitation processes in an Al-2.5Cu-1.5Mg (wt.\%) alloy microalloyed with Ag and Si. Acta Mater. 2003, 51, 5037-5050. [CrossRef] 
22. Telesshov, V.V.; Andreev, D.A.; Golovleva, A.P. Effect of chemical composition on the strength of alloy of the Al-Cu-Mg-Ag system after heating at $180-210^{\circ} \mathrm{C}$. Met. Sci. Heat Treat. 2006, 48, 104-112. [CrossRef]

23. Song, M.; Xiao, D.; Zhang, F. Effect of Ce on the termal stability of the $\Omega$ phase in an Al-Cu-Mg-Ag alloy. Rare Met. 2009, 28, 156-159. [CrossRef]

24. Hutchinson, C.R.; Fan, X.; Pennycook, S.J.; Shiflet, G.J. On the origin of the high coarsening resistance of $\Omega$ plates in Al-Cu-Mg-Ag Alloys. Acta Mater. 2001, 49, 2827-2841. [CrossRef]

25. Allen, W.; Mahorter, R.; Erthal, J.; Williams, F.S. NAEC-AML-2083; Naval Air Engineering Center: Philadelphia, PA, USA, 1964.

26. Werner-Juszczuk, A.J. The influence of the thickness of an aluminium radiant sheet on the performance of the lightweight floor heating. J. Build. Eng. 2021, 44, 102896. [CrossRef]

27. Różyło, P. Optimization of I-section Profile Design by the Finite Element Method. Adv. Sci. Technol. Res. J. 2016, 10, 52-56. [CrossRef]

28. Kenji, K.; Tetsuro, H.; Tomoharu, T.; Horita, Z. Fabrication and characterization of supersaturated Al-Mg alloys by severe plastic deformation and their mechanical properties. Mater. Trans. 2009, 50, 76-81.

29. Jandaghi, M.R.; Pouraliakbar, H. Elucidating the microscopic origin of electrochemical corrosion and electrical conductivity by lattice response to severe plastic deformation in Al-Mn-Si alloy. Mater. Res. Bull. 2018, 108, 195-206. [CrossRef]

30. Alexandre, G.; Tsutomu, I.; Xiaoyong, Y.; Yoshinobu, M.; Goroh, I. Friction stir welding of a commercial 7075-T6 aluminium alloy: Grain refinement, thermal stability and tensile properties. Mater. Trans. 2004, 45, 2503-2508.

31. Roberto, B.F.; Terence, G.L. Using severe plastic deformation for the processing of advanced engineering materials. Mater. Trans. 2009, 50, 1613-1619.

32. Chen, X.H.; Lu, L.; Lu, K. Grain size dependence of tensile properties in ultrafine-grained Cu with nanoscale twins. Scr. Mater. 2011, 64, 311-314. [CrossRef]

33. Callister, W.D. Materials Science and Engineering: An Introduction, 4th ed.; John Willey and Son Inc.: New York, NY, USA, 1997.

34. Jandaghi, M.R.; Pouraliakbar, H.; Saboori, A. Effect of second-phase particles evolution and lattice transformations while ultrafine graining and annealing on the corrosion resistance and electrical conductivity of Al-Mn-Si alloy. Mater. Res. Express 2019, 6, 1065d9. [CrossRef] 